\title{
Relationship Relationship Between Income and Food Quality of the Population of the Republic of Kazakhstan
}

\author{
A.I. Gizzatova ${ }^{1 *}$, S.M. Yessengaliyeva ${ }^{2}$, A.M. Kazambaeva ${ }^{2}$ \\ ${ }^{1}$ West Kazakhstan University named after M. Utemisov, 162 N. Nazarbayev Ave., 090009, Uralsk, \\ Kazakhstan \\ ${ }^{2}$ West Kazakhstan Agrarian Technical University named after Zhangir Khan, 51 Zhangir Khan Str., \\ 090009, Uralsk, Kazakhstan
}

\begin{abstract}
The purpose of the article is to study the relationship between the income level and the quality of nutrition of the population of the republic, per capita consumption of basic foodstuffs by population groups with different disposable incomes, the main problems, and ways to solve them. The main source of information was the official data of the Bureau of National Statistics of the Agency for Strategic Planning and Reforms of the Republic of Kazakhstan. The theoretical basis of the research was the works of domestic and foreign scientists in the field of the level and quality of life, materials of the FAO. The study was conducted using general scientific methods of cognition, as well as special methods of economic and statistical analysis - grouping, graphical research method, ranking of the dynamic series, calculated indicators of the analysis of dynamic series. The scientific novelty of the study is to assess the impact of changes in disposable income on the concentration and differentiation of income of the population, food consumption in different income groups of the population of the republic. The authors analyzed the main modern concepts of measuring the standard of living and selected the most acceptable information from the point of view of accessibility, which was the basis of the study. The results of the study can be used in the formation of medium- and long-term programs to increase the income and quality of nutrition of the population, as well as a basis for further research in this direction.
\end{abstract} practice

Keywords: standard of living, quality of life, quality of food, income, food consumption rates, expenses, food,

For citation: Gizzatova, A.I., Yessengaliyeva, S.M.. \& Kazambaeva A.M. (2021). Relationship Relationship Between Income and Food Quality of the Population of the Republic of Kazakhstan. Economics: the Strategy and Practice, 16(4), 218-229, https://doi.org/10.51176/1997-9967-2021-4 -218-229

* Corresponding author: Salta M. Yessengaliyeva - Doctor PhD, Ph.D. (RF), acting Associate Professor, West Kazakhstan Agrarian Technical University named after Zhangir Khan, 51 Zhangir Khan Str., 090009, Uralsk, Kazakhstan, 8747292 5229, e-mail: salta_em@mail.ru

Conflict of interests: the authors declare that there is no conflict of interest.

Financial support: The study was not sponsored (own resources).

The article received: 23.11 .2021

The article approved for publication: 29.12 .2021

Date of publication: 30.12 .2021 


\title{
Қазақстан Республикасының тұрғындардың табысы мен тамақтану сапасының өзара байланысы
}

\author{
Гиззатова А.И. ${ }^{*}$, Есенгалиева С.М. ${ }^{*}$, Казамбаева А.М. ${ }^{2}$ \\ ${ }^{1}$ М.Өтемисов атындавы Батыс Қазақсстан университеті, 090009, Н.Назарбаев данъвылы, 162, \\ Орал., Қазақсттан \\ 2Жәнугір хан атындавы Батыс Қазақсстан аграрлық-техникалық университеті, Жәнгір хан к., 51, \\ 090009, Орал., Қазақ̧стан
}

\begin{abstract}
Түйін
Мақаланың мақсаты республика халқының табыс деңгейі мен тамақтану сапасының өзара байланысын, әртүрлі қолда бар табыстары бар халық топтары бойынша негізгі тамақ өнімдерін жан басына шаққандағы тұтынуды, негізгі проблемалар мен оларды шешу жолдарын зерттеу болып табылады. Ақпараттың негізгі көзі Қазақстан Республикасының Стратегиялық жоспарлау және реформалар жөніндегі агенттігінің ұлттық статистика бюросының ресми деректері болды. Зерттеудің теориялық негізі өмір сүру деңгейі мен сапасы саласындағы отандық және шетелдік ғалымдардың еңбектері, ФАО материалдары болды. Зерттеу танымның жалпы ғылыми әдістерін, сондай-ақ экономикалық - статистикалық талдаудың арнайы әдістерін-топтастыруды, зерттеудің графикалық әдісін, динамикалық қатарларды саралауды қолдана отырып жүргізілді, динамикалық қатарларды талдау көрсеткіштерін есептеді. Зерттеудің ғылыми жаңалығы қолда бар ақшалай табыстардың өзгеруінің халықтың табыстарының шоғырлануы мен саралануына, республика халқының табысы бойынша әртүрлі топтарындағы азық-түлікті тұтынуға әсерін бағалау болып табылады. Авторлар өмір сүру деңгейін өлшеудің негізгі заманауи тұжырымдамаларын талдады және зерттеудің негізіне алынған қол жетімділік тұрғысынан ең қолайлы ақпаратты таңдады. Зерттеу нәтижелері халықтың табысы мен тамақтану сапасын арттыру жөніндегі орта және ұзақ мерзімді бағдарламаларды қалыптастыруда, сондай-ақ осы бағыттағы әрі қарайғы зерттеулердің негізі ретінде пайдаланылуы мүмкін.
\end{abstract}

Түйін сөздер: өмір сүру деңгейі, тамақтану сапасы, кірістер, азық-түлікті тұтыну мөлшері, шығыстар, азық-түлік, тәжірибе

Дәйексөз алу үшін: Гиззатова А.И., Есенгалиев С.М., Казамбаева А.М. (2021). Қазақстан Республикасының тұрғындардың табысы мен тамақтану сапасының өзара байланысы. Экономика: стратегия және практика, 16(4), 218-229, https://doi.org/10.51176/1997-9967-2021-4 -218-229

* Хат-хабаршы авторы: Есенгалиева С.М. - PhD докторы, э.ғ.к. (РФ), доцента м.а., Жәңгір хан атындағы Батыс Қазақстан аграрлық-техникалық университеті, Жәңгір хан к., 51, 090009, Орал қ., Қазақстан, 8747292 5229, e-mail: salta em@mail.ru

Мүдделер қақтығысы: авторлар мүдделер қақтығысының жоқтығын мәлімдейді.

Қаржыландыру. Зерттеу демеушілік қолдау көрсеткен жоқ (меншікті ресурстар).

Мақала редакцияға түсті: 23.11 .2021

Жариялау туралы шешім қабылданды: 29.12.2021

Жарияланды: 30.12 .2021 


\title{
Взаимосвязь располагаемого дохода и качества питания населения Республики Казахстан
}

\author{
Гиззатова А.И. ${ }^{1}$, Есенгалиева С.М. ${ }^{2 *}$, Казамбаева А.М. ${ }^{2}$ \\ 'Западно-Казахстанский университет им М.Утемисова, пр. Н.Назарбаева 162, \\ 090009, Уральск, Казахстан \\ 23 Запано-Казахстанский аграрно-технический университет им. Жангир хана, \\ ул. Жангир хана 51, 090009, Уральск, Казахстан
}

\begin{abstract}
Аннотация
Целью статьи является исследование взаимосвязи уровня дохода и качества питания населения республики, душевого потребления основных продуктов питания по группам населения с различными располагаемыми доходами, выявление основных проблем и путей их решения. Основным источником информации выступили официальные данные Бюро национальной статистики Агентства по стратегическому планированию и реформам Республики Казахстан. Теоретической базой исследования послужили труды отечественных и зарубежных ученых в области уровня и качества жизни, материалы ФАО. Исследование проводилось с использованием общенаучных методов познания, а также специальных методов экономикостатистического анализа - группировки, графического метода исследования, ранжирования динамического ряда, рассчитывались показатели анализа динамических рядов.Научная новизна исследования заключается в оценке влияния изменения располагаемых денежных доходов на концентрацию и дифференциацию доходов населения, потребление продовольствия в разных по доходу группах населения республики. Авторами проанализированы основные современные концепции измерения уровня жизни и выбрана наиболее приемлемая с точки зрения доступности информации концепция, которая была положена в основу исследования. Результаты исследования могут быть использованы при формировании средне- и долгосрочных программ по повышению доходов и качества питания населения, а также в качестве основы дальнейших исследований в этом направлении.
\end{abstract}

Ключевые слова: уровень жизни, качество питания, доходы, нормы потребления продовольствия, расходы, продовольствие, практика

Для цитирования: Гиззатова А.И., Есенгалиева С.М., Казамбаева А.М. (2021). Взаимосвязь располагаемого дохода и качества питания населения Республики Казахстан. Экономика: стратегия и практика, 16(4), 218229, https://doi.org/10.51176/1997-9967-2021-4-218-229

* Корреспондирующий автор: Есенгалиева С.М. - доктор $\mathrm{PhD}$, к.э.н. (РФ), и.о. доцента, ЗападноКазахстанский аграрно-технический университет им. Жангир хана, ул. Жангир хана 51, 090009, Уральск, Казахстан, 8747292 5229, e-mail: salta_em@mail.ru

Конфликт интересов: авторы заявляют об отсутствии конфликта интересов.

Финансирование. Исследование не имело спонсорской поддержки (собственные ресурсы).

Статья поступила в редакцию: 23.11 .2021

Принято решение о публикации: 29.12 .2021

Опубликовано: 30.12 .2021 


\section{Введение}

Питание выступает основной, главной потребностью любого человека. Оно оказывает влияние на физическое и умственное развитие человека, а также способность адаптироваться в обществе и на другие параметры жизнедеятельности человека. Основные причины и факторы недостаточного и неполноценного питания в современном мире являются объектом внимания Продовольственной и сельскохозяйственной организации Объединенных Наций (ФАО). В Республике Казахстан наличие данной проблемы и ее значимость определены в ряде нормативных и правовых документов, а также исследованиях отечественных ученыхэкономистов Сатыбалдина А.А., Калиева Г.А., Гиззатовой А.И. Есенгалиевой С.М. и других исследователей.

Особенность данной проблемы в том, что в республике углубляется дифференциация населения по доходам. Она оказывает влияние на показатели среднедушевого потребления продовольствия, а также на показатели потребления в различных по доходам группах населения и качество жизни.

Целью исследования явилось проведение анализа взаимосвязи уровня дохода и качества питания населения республики, выявление основных проблем и определение путей их решения. В этой связи в задачи нашего исследования входило изучение при наличии доходного неравенства, имеющего место в республике, питания различных слоев населения в зависимости от уровня доходов, также в ходе исследования не учитывали фактора территориальных различий в покупательной способности национальной валюты.

\section{Литературный обзор}

Вопросами оценки уровня жизни человечество занимается издавна, о чем свидетельствует проведенный нами обзор литературных источников. Они рассматривались Аристотелем, У. Петти, Ф. Кенэ, И. Кантом, А.Смитом, Д. Риккардо и другими. Однако в разные исторические периоды степень внимания к данной проблеме была различной. Тем не менее, все они считали естественным и обыденным желание людей повышать свое материальное благополучие и определяли сложившийся уровень благополучия или благосостояния по тому, какое количество и какого качества потребительские блага были доступны их современникам. Так, А.Смит в своей работе «Исследование о природе и причинах богатства народов» спрашивает о том, почему «народ оказывается лучше или хуже снабженным всеми необходимыми предметами и удобствами, в каких он нуждается» [1, с. 17].

Научное осмысление вопросов, связанных с уровнем жизни населения, разработкой систем показателей для еe характеристики, как показывает ретроспективный анализ публикаций, началось в период зарождения капитализма. Зарождающемуся производству требовались принципиально новые для своего времени техника и технологии, а также рабочие и работники, которые могли бы их использовать. Новые рабочие и работники должны были иметь более высокую квалификацию и стать основой зарождающегося среднего класса. Структура их материальных, социальных и духовных потребностей усложняется. Также будут увеличиваться затраты средств на восстановление жизненной энергии, на образование, профессиональную подготовку, досуг. Следовательно, обеспечивающий просто выживание уровень жизни для них не пригоден. Уровень их жизни должен быть значительно выше.

Новые условия, правила взаимоотношений между людьми (институты) требовали дополнительных исследований, возникла необходимость разработки новых методик, терминов и показателей для характеристики уровня жизни населения [2]. Постепенно происходит смена акцентов исследований с политико-экономического к экономико-статистическому аспекту проблемы. Уже во второй половине XIX века исследователи больше внимания начинают уделять анализу реальных, сложившихся условий жизни, фактическому потреблению трудящихся масс. Начинается активное обсуждение самой сущности понятий об уровне жизни, его составляющих.

Ученые-теоретики считают, что первым термин «уровень жизни» употребил К.Маркс. Термин он использовал при исследовании стоимости рабочей силы, которую ученый раскладывал на два элемента. Одну часть К. Маркс называет физической, другую социальной. К. Маркс отмечал, что параллельно с удовлетворением потребностей физической жизни, необходимо удовлетворение потребностей, связанных со сложившимися общественными условиями, т.е. социальной составляющей. Каждая из этих частей должна быть удовлетворена [3].

Существенный вклад в развитие теории и практики формирования финансовых предпосылок, повышения уровня жизни населения внесли экономисты-теоретики К. Маркс, 
А. Маршалл, Дж. М. Кейнс и другие. Уже в 20 веке Дж. Б. Кларк писал, что «Благосостояние наемных работников зависит от того, получают они много или мало; ....» [4].

Изучение научных публикаций по рассматриваемой проблеме показывает, что к настоящему времени в мире значительно расширился круг, как профессиональных исследователей, так и пользователей результатами измерения показателя уровня жизни. На практике возрастают требования к точности, надежности, объективности информации для оценки сложившегося уровня жизни и прогнозирования перспектив. С целью получения достоверной и качественной информации с 20-х годов XX века стали проводиться Бюджетные обследования, представляющие собой Выборочные статистические обследования (случайную выборку единиц наблюдения), доходов и расходов семей (домашних хозяйств). С ростом требований к качеству и количеству информации с конца XX столетия стали проводиться более широкие обследования уровня жизни [5].

Для обеспечения взаимной сопоставимости показателей уровня жизни отдельных стран, были созданы международные и региональные статистические организации, в частности, Статистическая служба $\mathrm{OOH}$, ЕВРОСТАТ, Группа Канберра и другие. Разработкой Методологии международных сопоставлений уровня жизни занимаются также Международная Организация Труда (МОТ) и Всемирный Банк.

Отсутствие единого подхода к определению самого понятия, к выбору компонентов, входящих в его состав приводит к появлению различных концепций. Исследования показывают, что в настоящее время активно обсуждаются четыре концепции, отражающие последовательные стадии взаимодействия человека с располагаемыми потребительскими благами [5]. Первые две концепции принято называть традиционными, две другие были предложены лауреатом Нобелевской премии А. Сеном [6].

Первая традиционная концепция оперирует количеством и качеством благ окружающих индивида, отражает тем самым объективную сторону жизни.

Другая традиционная концепция определяет уровень жизни как ее полезность. Определение полезности было дано в конце XVIII в. И. Бентамом [7]. В современной модификации этой концепции полезность отождествляется с осуществлением желаний. Основное внимание здесь уделяется человеку, a не внешним условиям его жизни. Данной проблеме присущи свои концептуальные и эмпирические проблемы, обсуждение которых представлено в работах исследователей [8].

Критикуя традиционные подходы к определению уровня жизни и, считая, что они не выполняют свою задачу, лауреат Нобелевской премии А. Сен предложил две другие концепции уровня жизни - концепцию «фактического уровня жизни человека» и концепцию «располагаемых возможностей» или «индивидуальной свободы выбора» [9]. Исследователи отмечают теоретический характер этих концепций и невозможность реализации из-за отсутствия необходимой статистической базы [5].

Вопросами уровня, качества жизни занимаются и казахстанские ученыеэкономисты: А.А. Сатыбалдин [10], Г.А. Калиев [11], А.И. Гиззатова [12], С.М. Есенгалиева [13], Бримбетова Н.Ж. [14] и другие. Вместе с тем, как отмечают исследователи, становится ясным, что при исследовании качества жизни, первоочередным выступает исследование доступности и качества питания населения.

\section{Методология}

В процессе исследования помимо общенаучных методов познания: научная абстракция, индуктивный, дедук-тивный, сравнительный анализ, использова-лись методы экономико-статистического анализа динамики и структуры, также были применены методы группировки и ранжирования ряда, определения уровней динамического ряда, метод сопоставлений. Научной базой исследования явились публикации ученых, занимающихся данной проблемой. Информационной базой послужили законодательные и нормативно-правовые акты Республики Казахстан, официальные данные Бюро национальной статистики Агентства по стратегическому планированию и реформам Республики Казахстан.

Исследованиями было выявлено, что наиболее приемлемой для нашего исследования является подход, опирающийся на измерении обеспеченности индивида потребительскими благами, используемый как казахстанскими, так зарубежными исследователями (А.А. Сатыбалдин, Г.А. Калиев, А.И. Гиззатова, С.М. Есенгалиева, А.А.Подузов и другие). При исследовании качества питания населения, как правило, основной акцент делается на количество потребляемого продовольствия в среднем по стране и долю расходов на продовольствие. Особенностью данного исследования является использование методов экономического анализа для 
изучения изменений распределения располагаемого денежного дохода по группам населения республики, а также изменений душевого потребления основных продуктов питания в среднем по республике и по группам населения с различными располагаемыми денежными доходами.

\section{Результаты и обсуждение}

В современном мире наиболее используемой в реальной практике является концепция, которая понимает уровень жизни как обеспеченность и зависит от дохода [5]. Официальная статистическая практика основана на определении дохода, сформулированном Дж. Р. Хиксом, одним из создателей современной версии системы национальных счетов [15, с. 291].

В ходе исследования нами были изучены результаты работ по анализу определенных систем показателей, используемых для характеристики качества жизни, выполненных казахстанскими и зарубежными исследователями [16, 17]. Они свидетельствуют, что показатели, характеризующие качество питания занимают особое место в этих системах и могут входить в систему прямо (Прокушев Е.В. и Лихонин Е.П.) или косвенно (индекс человеческого развития). От состава и структуры потребляемых продуктов питания, от сбалансированности и калорийности питания зависят работоспособность индивида, производительность его труда. Последнее оказывает влияние на его денежные доходы. Нами был проведен анализ официальных данных о динамике индексов номинальных и реальных денежных доходов населения республики за период с 2015-2020 гг. [18]. Статистические данные о поведении этих показателей по годам представлены на рисунке 1 .

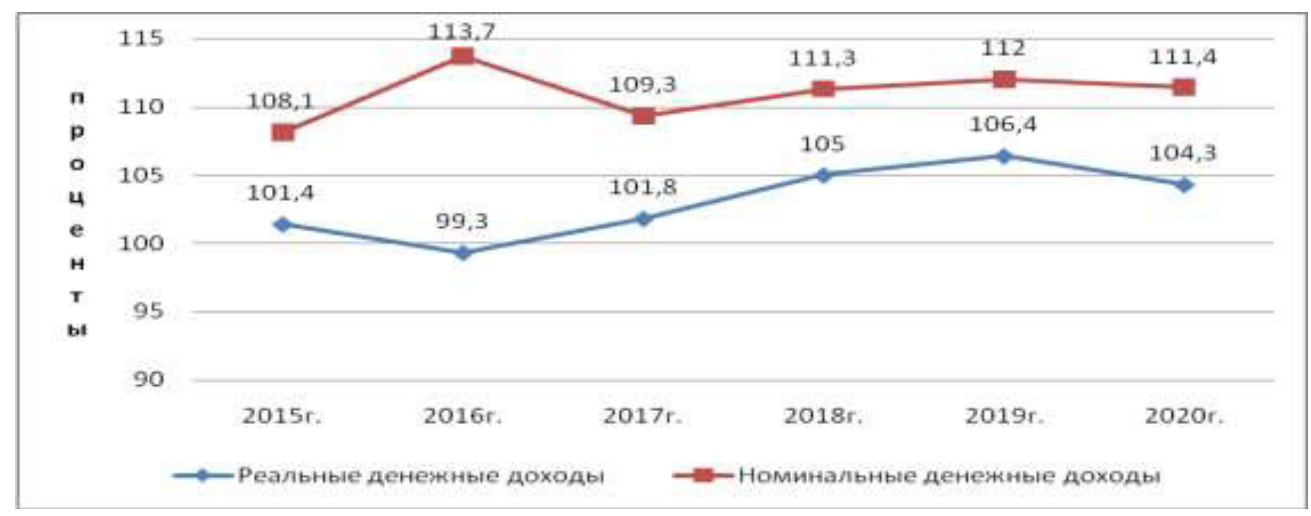

Рисунок 1 - Индексы номинальных и реальных денежных доходов населения в Республике Казахстан, 2015-2020 гг.

Table 1 - Indices of nominal and real money incomes of the population in the Republic of Kazakhstan, 2015-2020

Примечание - Составлено авторами по источнику [18].

Эти данные показывают, что начиная с 2016 года в республике наблюдалось увеличение темпов роста реальных, а с 2017 г. - номинальных денежных доходов населения. В 2019 г. относительно 2018 г. номинальные денежные доходы населения выросли - на $0,7 \%$, реальные - на 1,4 \%, однако в 2020 г. темпы роста замедлились. В 2020 г. относительно предыдущего года темп роста реальных денежных доходов снизился на 2,1 п.п., а номинальных - на 0,6 п.п. Следующим шагом нашего исследования было рассмотреть на основании данных официальной статистики [18] влияние такого изменения на показатели дифференциации населения по их располагаемым денежным доходам. Результаты представлены в таблице 1. 


\section{BUSINESS AND ENTREPRENEURSHIP}

Таблица 1 - Неравномерность распределения доходов населения Республики Казахстан, 2015-2020 гг. Table 1 - Uneven distribution of incomes of the population of the Republic of Kazakhstan, 2015-2020

\begin{tabular}{|c|c|c|c|c|}
\hline \multirow[b]{2}{*}{ Годы } & \multicolumn{2}{|c|}{ Доля населения с доходами ниже } & \multirow[b]{2}{*}{$\begin{array}{c}\text { Коэффициент Джини } \\
\text { по 10\% группам } \\
\text { населения }\end{array}$} & \multirow{2}{*}{$\begin{array}{c}\text { Соотношение } \\
\text { доходов } 10 \% \\
\text { наиболее и наименее } \\
\text { обеспеченного } \\
\text { населения, раз }\end{array}$} \\
\hline & $\begin{array}{c}\text { величины } \\
\text { прожиточного } \\
\text { минимума, \% }\end{array}$ & $\begin{array}{c}\text { стоимости } \\
\text { продовольственной } \\
\text { корзины, \% }\end{array}$ & & \\
\hline 2015 & 2,6 & 0,1 & 0,278 & 5,6 \\
\hline 2016 & 2,5 & 0,1 & 0,278 & 5,6 \\
\hline 2017 & 2,7 & 0,1 & 0,287 & 5,9 \\
\hline 2018 & 4,3 & 0,1 & 0,289 & 6,0 \\
\hline 2019 & 4,3 & 0,1 & 0,290 & 6,0 \\
\hline 2020 & 5,3 & 0,2 & 0,291 & 5,9 \\
\hline
\end{tabular}

Примечание - Составлено авторами по источнику [18]

Данные таблицы показывают, что если в 2015-2017 гг. доля населения с доходами, ниже величины прожиточного минимума, была относительно стабильна. В последующие годы доля этой категории населения в республике увеличилась с 2,7 \% в 2017 г. до 4,3\% в 2018 г. или на 1,6 п.п. и в 2019 г. сохранилась на этом же уровне. В 2020 г. доля этой группы населения увеличилась до 5,3\% или на 1 п.п. относительно предыдущего года. В 2020 г. также увеличилась доля населения, имеющего доходы ниже стоимости продовольственной корзины. Таким образом, снижение темпов роста реальных и номинальных денежных доходов населения республики привело к увеличению доли бедного населения.
Для оценки степени неравенства доходов принято использовать коэффициент Джини. Коэффициент Джини по 10\% группам населения, представленный официальной статистикой [18] показывает, что в республике наблюдается устойчивая тенденция увеличения степени отклонения фактического распределения доходов по численно равным (в нашем случае - децильным) группам населения от линии их равномерного распределения.

Информация для анализа распределения общего объема денежных доходов по различным группам населения (в частности, квинтильным группам) представлена в таблице 2.

Таблица 2 - Денежные доходы населения Республики Казахстан в 2016-2020 гг.

Table 2 - Cash incomes of the population of the Republic of Kazakhstan in 2016-2020

\begin{tabular}{|c|c|c|c|c|c|}
\hline \multirow{2}{*}{ Показатели } & \multicolumn{5}{|c|}{ Годы } \\
\hline & 2016 & 2017 & 2018 & 2019 & 2020 \\
\hline Денежные доходы - всего & 100,0 & 100,0 & 100,0 & 100,0 & 100,0 \\
\hline в том числе по 20-процентным группам населения: & \multirow[b]{2}{*}{9,50} & \multirow[b]{2}{*}{9,30} & \multirow[b]{2}{*}{9,32} & \multirow[b]{2}{*}{9,36} & \multirow[b]{2}{*}{9.42} \\
\hline первая (с наименьшими доходами) & & & & & \\
\hline вторая & 13,26 & 13,02 & 13,02 & 12,93 & 12,86 \\
\hline третья & 16,99 & 16,71 & 16,53 & 16,51 & 16,38 \\
\hline четвертая & 22,28 & 22,19 & 21,98 & 21,95 & 21,94 \\
\hline пятая с (наивысшими доходами) & 37,97 & 38,78 & 39,15 & 39,25 & 39,40 \\
\hline $\begin{array}{l}\text { Коэффициент концентрации доходов (индекс Джини, } \\
\text { по 10-процентным группам населения) }\end{array}$ & 0,278 & 0,287 & 0,289 & 0,290 & 0,291 \\
\hline $\begin{array}{l}\text { Коэффициент фондов (соотношение 10\% наиболее и } \\
\text { наименее обеспеченного населения), раз }\end{array}$ & 5,6 & 5,9 & 6,0 & 6,0 & 5,9 \\
\hline
\end{tabular}

Примечание - Составлено авторами по источнику [18]

Данные таблицы свидетельствуют, что в рассматриваемый период в республике при снижении темпов роста реальных и номинальных доходов населения, происходили процессы перераспределения денежных доходов по выделенным группам. Если в 2016 г. на долю 20\% наиболее обеспеченной части населения приходилось $37,97 \%$ всего 
денежного дохода, то в 2020 г. эта группа населения сосредоточила у себя 39,40\% всего денежного дохода, т.е. их денежный доход вырос на 1,43 п.п.

Доход наименее обеспеченной части населения в 2016 г. составлял 9,50\% от общей суммы, а в 2020 г. - только 9,42\%, т.е. имело место сокращение дохода этой группы на 0,08\% п.п. Положительным фактом является то, что в 2020 г. относительно 2019 г. доля дохода это группы выросла с 9,36\% до 9,48\% или на $0,12 \%$.

По данным официальной статистики [18] в 2020 г. средний денежный доход одного человека из $10 \%$ группы наименее обеспеченного населения составила 390076 тенге, а из наиболее обеспеченной части 1350742 тенге в год.

Значение коэффициента Джини, как индекса концентрации доходов, в исследуемый период увеличилось с 0, 278\% в 2016 г. до 0,291\% в 2020 г., что свидетельствует об увеличении отклонения фактического распределения доходов по численно равным децильным группам населения от линии их равномерного распределения.

Исследователи отмечают, что коэффициент фондов, как коэффициент дифференциации доходов и коэффициент Джини представляют собой довольно устойчивую характеристику распределения, так как не зависят от влияния крайних значений в распределении изучаемого признака [16, стр. 823].
Произошедшие

изменения

B распределении денежных доходов явились одной из причин изменения в 2016-2020 годы структуры потребительских расходов населения республики. Анализ официальных данных [18] показывает, что в структуре расходов населения доля расходов на продовольственные товары с 2016 по 2020 годы увеличилась с $45,8 \%$ до $53,9 \%$.

В структуре потребительских расходов населения за данный период расходы на продовольственные товары выросли с 49,3\% до $58,0 \%$. В их составе расходы на продукты питания выросли за данный период с 45,1\% до $54,2 \%$.

Увеличение расходов на продовольствие при сокращении реальных денежных доходов на практике в определенных условиях приводит к замещению более качественного продовольствия менее качественным, но более дешевым. По свидетельству исследователей, a также изучение статистических данных показывает, что высокая доля расходов на продовольствие характерна для бедных и развивающихся стран.

Ранее нами было отмечено снижение реальных денежных доходов населения и увеличение доли доходов, израсходованных (потраченных) на продовольствие. Эти изменения оказались факторами, среди прочих факторов, приведших к увеличению потребления продовольствия, т.е. к увеличению платежеспособного спроса на основные виды продуктов питания. Данные официальной статистики [18] о потреблении основных продуктов питания в Республике Казахстан в 2015-2019 годы представлены в таблице 3.

Таблица 3 - Потребление основных продуктов питания в 2016-2020 годы в Республике Казахстан Table 3 - Consumption of basic food products in 2016-2020 in the Republic of Kazakhstan

на 1 члена домашнего хозяйства в месяц, кг

\begin{tabular}{|l|c|c|c|c|c|c|}
\hline \multicolumn{1}{|c|}{ Наименование } & 2016 г. & 2017 г. & 2018 г. & 2019 г. & 2020 г. & $\begin{array}{c}2020 \text { г. } \\
\text { в \% к 2016 г. }\end{array}$ \\
\hline $\begin{array}{l}\text { Хлебопродукты и крупяные } \\
\text { изделия }\end{array}$ & 10,9 & 11,1 & 11,5 & 11,4 & 11,4 & 104,6 \\
\hline Мясо и мясопродукты & 6,1 & 6,1 & 6,5 & 6,6 & 7,0 & 114,8 \\
\hline Рыба и морепродукты & 0,9 & 0,9 & 1,1 & 1,2 & 1,3 & 144,4 \\
\hline Молочные продукты & 19,6 & 19,8 & 21,8 & 21,1 & 21,6 & 110,2 \\
\hline Яйца, шт & 13,7 & 14,0 & 16,1 & 16,2 & 16,6 & 121,2 \\
\hline Масла и жиры & 1,6 & 1,6 & 1,6 & 1,4 & 1,4 & 87,5 \\
\hline Фрукты & 5,1 & 5,4 & 6,2 & 6,4 & 6,6 & 129,4 \\
\hline Овощи & 7,4 & 7,4 & 7,8 & 7,2 & 7,2 & 97,3 \\
\hline Картофель & 4,0 & 3,9 & 4,0 & 4,0 & 4,2 & 105,0 \\
\hline $\begin{array}{l}\text { Сахар, кондитерские изделия и } \\
\text { сладости }\end{array}$ & 3,4 & 3,4 & 3,9 & 3,6 & 3,6 & 102,9 \\
\hline
\end{tabular}

Примечание - Составлено авторами по источнику [18] 
Данные таблицы 3 показывают, что в период с 2016 по 2020 годы наиболее значительно увеличилось потребление всех основных видов продовольствия, за исключением масла и жиров и овощей, потребление которых сократилось.

Как было ранее нами отмечено в республике в 2016-2020 гг. усилилась дифференциа- ция населения по доходам. Для выявления изменений в потреблении продовольствия в 10\%-ных группах наименее и наиболее обеспеченного населения и соответствия рациональным нормам потребления продовольствия [19] населением республики использовали данные, представленные в таблице 4.

Таблица 4 - Потребление основных продуктов питания в домохозяйствах различного уровня дохода Table 4 - Consumption of basic foodstuffs in households of different income levels

на 1 члена домашнего хозяйства в месяц, кг

\begin{tabular}{|c|c|c|c|c|c|c|c|}
\hline \multirow[t]{2}{*}{ Наименование } & \multirow{2}{*}{$\begin{array}{c}\text { Научно- } \\
\text { обоснованные } \\
\text { нормы } \\
\text { потребления }\end{array}$} & \multicolumn{2}{|c|}{ Все домохозяйства } & \multicolumn{2}{|c|}{$\begin{array}{c}\text { 10\% наименее } \\
\text { обеспеченного } \\
\text { населения }\end{array}$} & \multicolumn{2}{|c|}{$\begin{array}{c}10 \% \text { наиболее } \\
\text { обеспеченного } \\
\text { населения }\end{array}$} \\
\hline & & 2019г. & 2020 г. & 2019 г. & $2020 \Gamma$ & $2019 \Gamma$ & $2020 \Gamma$ \\
\hline $\begin{array}{l}\text { Хлебопродукты и } \\
\text { крупяные изделия }\end{array}$ & 9,1 & 11,4 & 11,4 & 9,9 & 9,8 & 14,5 & 15,6 \\
\hline Мясо и мясопродукты & 6,5 & 6,6 & 7,0 & 3,6 & 3,7 & 11,4 & 12,6 \\
\hline Рыба и морепродукты & 1,2 & 1,2 & 1,3 & 0,7 & 0,6 & 2,3 & 2,6 \\
\hline Молочные продукты & 25,1 & 21,1 & 21,6 & 12,3 & 12,3 & 36,8 & 38,6 \\
\hline Яйца, шт & 22,1 & 16,2 & 16,6 & 9,5 & 9,6 & 27,1 & 28,6 \\
\hline Масла и жиры & 1,4 & 1,4 & 1,4 & 1,1 & 1,1 & 2,0 & 2,2 \\
\hline Фрукты & 11,0 & 6,4 & 6,6 & 3,6 & 3,6 & 11,7 & 12,2 \\
\hline Овощи & 12,4 & 7,2 & 7,2 & 5,0 & 5,0 & 11,2 & 11,7 \\
\hline Картофель & 8,3 & 4,0 & 4,2 & 2,9 & 2,8 & 5,9 & 6,3 \\
\hline $\begin{array}{l}\text { Сахар, кондитерские } \\
\text { изделия и сладости }\end{array}$ & 2,8 & 3,6 & 3,6 & 2,5 & 2,3 & 5,4 & 5,8 \\
\hline
\end{tabular}

Примечание - Составлено авторами по источнику [18]

Приведенные данные свидетельствуют, что в 2020 г. относительно 2019 г. незначительно сократилось потребление бедным населением рыбы и морепродуктов, картофеля и сахаросодержащих продуктов. Низкий уровень денежных доходов, даже при некотором их увеличении, стал одним из факторов снижения платежеспособного спроса на основные виды продовольствия. В свою очередь, низкий уровень потребления привел к тому, что практически все продукты потреблялись в объемах, меньших, чем в среднем по республике, а также ниже научнообоснованных норм потребления в республике.

В группе наиболее обеспеченного населения потребление основных видов продовольствия, за исключением хлебопродуктов и крупяных изделий, наоборот, увеличилось. Данная группа обеспечивала потребление основных видов продовольствия выше научно-обоснованных норм, за исключением картофеля, потребление которого составляло 71,1\% от нормативного [19].

Наблюдаемая несбалансированность питания населения республики приводит к дисбалансу рациона питания и к увеличению заболеваний, связанных с дефицитом или избытком потребляемых веществ, а также болезнями, связанными с воздействием окружающей среды.

Проведенные исследования свидетельствуют, что при наличии проблем питания, становятся особенно важными вопросы формирования культуры питания у подростков - пищевого поведения, пищевой мотивации, пищевых привычек. Именно в подростковом периоде закладываются будущее здоровье, продолжительность жизни, именно от сегодняшних подростков зависит будущее нации.

\section{Выводы}

Казахстан переходит на развитие на основе концепции устойчивого роста, вместо концепции экономического роста. В соответствии с этим происходит корректировка основных критериев развития и параллельно с ВВП / ВНП рассматриваются параметры категории, определяемой как качество жизни, включая параметры оценки качества питания. 
В республике, как показывают проведенные исследования, в период до 2019 г. наблюдался рост номинальных и реальных доходов населения, что является свидетельством эффективности государственной политики. В 2020 г. произошло снижение темпов роста этих параметров. Последнее привело к усилению дифференциации населения по их доходам, увеличению доли бедного населения. Увеличивается доля расходов на продовольствие в потребительских расходах.

C сокращением реальных денежных доходов сократился платежеспособный спрос на продовольствие, особенно бедной ее части, происходит замещение качественного продовольствия менее качественным. Об этом свидетельствуют данные потребления продовольствия крайними децильными группами населения.

Сопоставление сложившегося уровня потребления основных видов продовольствия населением республики в среднем с рекомендованными, выявили на практике существенные отклонения в показателях. Было выявлено наличие несбалансированности в питании населения республики. Результаты показали, что бедная часть жителей потребляла в пределах рекомендованных норм только хлебобулочные и крупяные изделия.

Богатая часть населения и имела значительный переизбыток потребления всех видов продовольствия.

В связи с эти, учитывая роль и значение питания в возможности развития страны необходимы определенные меры по сокращению бедности посредством повышения реальных денежных доходов населения. Это обеспечит повышение спроса на продовольствие и сбалансированность питания всех групп жителей республики. В этих целях необходимы меры государства, направленные на:

- повышение эффективности рынка труда посредством обеспечения условий, при которых будут создаваться новые рабочие места;

- усиление контроля за функционированием программ бесплатного дошкольного и школьного питания, что позволит повысить уровень и качество питания этой группы;

- разработать и реализовать систему мероприятий по повышению культуры питания;

- обеспечить повышение пенсий и пособий по уходу за детьми, инвалидам, многодетным семьям, неполным семьям с маленькими детьми, что будет способствовать повышению платежеспособного спроса на продовольствие;

- разработать и реализовать программы по планированию семьи во всех регионах республики;

- необходимы исследования региональных различий стоимости жизни и влияния их на качество питания в регионах.

\section{Список использованных источников}

1. Смит А. (1962). Исследование о природе и причинах богатства народов. М.: Изд. Соц-эк. литературы.

2. Норт Д. (1997). Институты, институциональные изменения и функционирование экономики. Пер. с. англ. А.Н.Нестеренко: предисл. и научн. ред. Б.З.Мильнера. Ф.: Фонд экономической книги «Начала».

3. Маркс К. (1960). Сочинения: сентябрь 1864 - июль 1870. Изд. 2-е. М. : Государственное издательство политической литературы. Т. 16.

4. Дж. Б. Кларк. (2000). Распределение богатства. М. Гелиос АРВ.

5. Подузов А.А. (2008). Философия уровня жизни. Очерк современных представлений. Научные труды: Институт народнохозяйственного прогнозирования РАН, Т.6., С. 72-95.

6. Sen, A. (1987). The Standard of Living. Cambridge.

7. Bentham, J. (1961). An Introduction to the Principles of Morals and Legislation. N. Y.: In The Ut1ilitarians.

8. Sen, A. (1985). Commodities and Capabilities. Amsterdam.

9. Sen, A. (1996). Inequality Reexamined. Oxford. 10. Сатыбалдин, А.А., Темирова, Г.Қ., Жүнісбекова, Т.А. (2020). Қазақстанның азықтүлік қауіпсіздігі: жағдайы және мүмкіндігі. Экономика: стратегия и практика, 2 (15), 5-14. 5 https://doi.org/10.51176/JESP/issue 2 T1

11. Калиев Г.А. (2008). Обеспечение продовольственной безопасности стран СНГ. Г.А.Калиев. Материалы международной конференции «Коллективная продовольственная безопасность стран СНГ: проблемы и пути их решения». - Алматы: НИИ экономики АПК и развития сельских территорий, АО «КазАгроИнновация», 481 с.

12. Гиззатова А.И. (2018). Вопросы теории и практики агропродовольственного рынка Республики Казахстан: Монография, Уральск: РИЦ ЗКГУ им. М.Утемисова.

13. Гиззатова А.И., Есенгалиева С.M, Абулкасова Д.Б., Султангужиева А.Ж. (2021). Уровень жизни и качество питания населения Республики Казахстан. Вестник Алтайской академии экономики и права, (5-2), 151-157.

14. Бримбетов, Н. Ж., Темирова Г.Қ., Султанаев А.А. (2020). Өнім сапасы және Қазақстан аймақтарын азық-түлікпен қамтамасыз ету: проблема- 


\section{BUSINESS AND ENTREPRENEURSHIP}

лары мен мүмкіндіктері. Экономика: стратегия и практика, 4 (15), 59-71.

15. Хикс Дж. Р. (1993). Стоимость и капитал. Москва: Издательская группа «Прогресс».

16. Суринов А.Е., Луппов А.Б. (2021). Влияние региональных различий стоимости жизни на национальные оценки неравенства по доходам. Экономика региона. Т. 17, вып. (3), 814-827. https:// doi.org/10.17059/ekon. reg.2021-3-7.

17. Прокушев Е.В., Лихонин Е.П. (2008). Основные показатели качества жизни. Вопросы структуризации экономики. (Т. 4), 26-27.

18. Уровень жизни населения в Казахстане / Статистический сборник. Министерство национальной экономики Республики Казахстан. Комитет по статистике. (2020). Нур-Султан. 81 с. URL: http:// www.stat.gov.kz. Дата обращения: 22.11.2021.

19. Научно-обоснованные физиологические нормы потребления продуктов питания. [Электронный pecypc]. http:///online.Әділет.kz. Дата обращения 22.11.2021.

\section{References}

1. Smit, A. (1962). [Research on the nature and causes of the wealth of peoples]. M.: Izd. Soc-jek. literatury, (In Russ.)

2. Nort, D. (1997). [Institutions, institutional change and the functioning of the economy] $\backslash$ Per. s. angl. A.N.Nesterenko: predisl. i nauchn. red. B.Z.Mil'nera. F.: Fond jekonomicheskoj knigi «Nachala», $180 \mathrm{~s}$ (In Russ.)

3. Marks, K. (1960). [Works: September 1864 - July 1870]. K. Marks, F. Jengel's. Izd. 2-e. - M. : Gosudarstvennoe izdatel'stvo politicheskoj literatury, $\mathrm{T}$. 16. 860 s (In Russ.)

4. Klark, Dzh. B (2000). [Distribution of wealth]. - M. Gelios ARV, S. 11 (In Russ.)

5. Poduzov, A.A. (2008). [Philosophy of living standards. An outline of contemporary views. Scientific works]: Institut narodnohozjajstvennogo prognozirovanija RAN, (T.6), 72-95 (In Russ.)

6. Sen, A. (1987). [The Standard of Living]. Cambridge.

7. Bentham, J. (1961). [An Introduction to the Principles of Morals and Legislation]. N. Y.: In The Ut1ilitarians.

8. Sen, A. (1985). [Commodities and Capabilities]. Amsterdam Oxford.

9. Sen, A. (1996). [Inequality Reexamined].

10. Satybaldin, A.A., Temirova, G.Қ., Zhynisbekova, T.A. (2020). [Food security in Kazakhstan: status and opportunities]. Jekonomika: strategija i praktika $=$ Economics: strategy and practice . 2 (15), 5-14.5 https://doi.org/10.51176/JESP/issue 2 T1(In Kaz.)

11. Kaliev, G.A. (2008). [Ensuring food security of the CIS countries] /G.A.Kaliev // Materialy mezhdunarodnoj konferencii «Kollektivnaja prodovol'stvennaja bezopasnost' stran SNG: problemy i puti ih reshenija». Almaty: NII jekonomiki APK i razvitija sel'skih territorij, AO «KazAgroInnovacija». (In Russ.)

12. Gizzatova, A.I. (2018). [Questions of theory and practice of the agri-food market of the Republic of Kazakhstan]. Monografija, Ural'sk: RIC ZKGU im. M.Utemisova. (In Russ.)

13. Gizzatova, A.I., Esengalieva, S.M, Abulkasova, D.B., Sultanguzhieva, A.Zh. (2021). [Living standards and nutritional quality of the population of the Republic of Kazakhstan]. Vestnik Altajskoj akademii jekonomiki i prava. (5-2), 151-157 (In Russ.)

14. Brimbetova, N.Zh., Temirova, G.K., Sultanaev, A.A. (2020). [Product quality and food security of the regions of Kazakhstan: problems and opportunities]. Jekonomika: strategija i praktika. Economics: strategy and practice. (4 (15), 59-71 (In Kaz.)

15. Hiks, Dzh. R. (1993). [Cost and capital]. Moskva. Izdatel'skaja gruppa «Progress», 448 s. (In Russ.)

16. Surinov, A.E., Luppov, A.B. (2021). [The influence of regional differences in the cost of living on national estimates of income inequality]. Jekonomika regiona. T. 17, (vyp. 3), 814-827. https:// doi.org/10.17059/ekon. reg.2021-3-7. (In Russ.)

17. Prokushev, E.V., Lihonin, E.P. (2008). [The main indicators of the quality of life]. Voprosy strukturizacii jekonomiki. (T. 4), 26-27. (In Russ.)

18. Uroven' zhizni naselenija v Kazahstane / Statisticheskij sbornik. Ministerstvo nacional'noj jekonomiki Respubliki Kazahstan. Komitet po statistike. Nut-Sultan. 2020. 81 s. URL: http:// www. stat.gov.kz, Data obrashhenija: 22.11.2021 (In Russ.)

19. Nauchno-obosnovannye fiziologicheskie normy potreblenija produktov pitanija. [Jelektronnyj resurs]. http:///online.Odilet.kz. Data obrashhenija 22.11.2021 (In Russ.) 


\section{Information about the authors}

A.I. Gizzatova - Doctor of Economics, Professor, West Kazakhstan University named after M. Utemisov, Kazakhstan, e-mail: alla-gizzatova@yandex.kz, ORCID ID: https://orcid.org/0000-0002-9664-7137

* S.M. Yessengaliyeva - Doctor PhD, Ph.D. (RF), acting Associate Professor, West Kazakhstan Agrarian Technical University named after Zhangir Khan, Kazakhstan, e-mail: salta_em@mail.ru, ORCID ID: https://orcid.org/00000002-6476-0282

A.M. Kazambaeva - Ph.D., Associate Professor, West Kazakhstan Agrarian Technical University named after Zhangir Khan, Kazakhstan, e-mail: aigul_aigul@bk.ru, ORCID ID: https://orcid.org/0000-0002-9947-4227

\section{Авторлар туралы мәліметтер}

Гиззатова А.И. - э.ғ.Д.,профессор, М.Өтемисов атындағы Батыс Қазақстан университеті, Қазақстан, е-таil: alla-gizzatova@yandex.kz, ORCID ID: https://orcid.org/0000-0002-9664-7137

* Есенгалиева С.M. - PhD докторы, э.ғ.к. (РФ), доцента м.а., Жәңгір хан атындағы Батыс Қазақстан аграрлық-техникалық университеті, Қазақстан, e-mail: salta_em@mail.ru, ORCID ID: https://orcid.org/00000002-6476-0282

Казамбаева А.М. - э.ғ.к., доцент, Жәңгір хан атындағы Батыс Қазақстан аграрлық-техникалық университеті, Қазақстан, e-mail: aigul_aigul@bk.ru, ORCID ID: https://orcid.org/0000-0002-9947-4227

\section{Сведения об авторах}

Гиззатова А.И. - д.э.н., профессор, Западно-Казахстанский университет им. М.Утемисова, Казахстан, е-таil: alla-gizzatova@yandex.kz, ORCID ID: https://orcid.org/0000-0002-9664-7137

* Есенгалиева С.М. - доктор $\mathrm{PhD}$, к.э.н. (РФ), и.о. доцента, Западно-Казахстанский аграрно-технический университет им. Жангир хана, Казахстан, e-mail: salta_em@mail.ru, ORCID ID: https://orcid.org/0000-00026476-0282

Казамбаева А.М. - к.э.н., доцент, Западно-Казахстанский аграрно-технический университет им. Жангир хана, Казахстан, e-mail: aigul_aigul@bk.ru, ORCID ID: https://orcid.org/0000-0002-9947-4227 